\title{
APLIKASI REGRESI KOMPONEN UTAMA UNTUK ANALISIS HUBUNGAN KUANTITATIF STRUKTUR-AKTIVITAS ANTIKANKER SENYAWA TURUNAN NAFTOQUINON
}

\author{
Andrian Saputra ${ }^{1, *}$, Ricky Andi Syahputra ${ }^{2}$, Iqmal Tahir ${ }^{3}$ \\ ${ }^{1}$ Jurusan Pendidikan Kimia, Fakultas Keguruan dan Ilmu Pendidikan, Universitas \\ Lampung, Bandar Lampung \\ ${ }^{2}$ Jurusan Kimia, Fakultas MIPA, Universitas Negeri Medan, Medan \\ ${ }^{3}$ Jurusan Kimia, Fakultas MIPA, Universitas Gadjah Mada, Sekip Utara, Yogyakarta \\ *Penulis kontak, tel : 0274-545188, email : andrian.chem@ mail.ugm.ac.id
}

\begin{abstract}
ABSTRAK
Kajian Hubungan Kuantitatif Struktur-Aktivitas (HKSA) senyawa antikanker turunan naftoquinon telah dilakukan dengan menggunakan analisis regresi komponen utama. Sebagai deskriptor digunakan muatan atom bersih dan beberapa deskriptor teoritik sebagai hasil perhitungan mekanika kuantum semiempirik PM3. Semua proses pemodelan molekul meliputi pembentukan struktur molekul, optimasi geometri dan perhitungan deskriptor molekul dilakukan menggunakan paket perangkat lunak Hyperchem 7.5. Data aktivitas biologis yang digunakan adalah data aktivitas antikanker senyawa melawan human cervical carcinoma dalam bentuk $\log \mathrm{IC}_{50}$. Setiap deskriptor molekul ditransformasi menjadi beberapa komponen utama sebagai variabel bebas pada analisis regresi terhadap $\log \mathrm{IC}_{50}$ guna mendapatkan model persamaan HKSA. Dengan pendekatan regresi komponen utama diperoleh model persamaan HKSA sebagai berikut :

$\log \mathrm{IC}_{\mathbf{5 0}}=0.719+0.324 \mathrm{x}_{\mathbf{1}}+\mathbf{0 . 0 1 8} \mathrm{x}_{\mathbf{2}}-\mathbf{0 . 1 8 3} \mathrm{x}_{\mathbf{3}}$

dengan $\mathrm{n}=13, \mathrm{r}=0,893, \mathrm{r}^{2}=0,797$, adjusted $\mathrm{r}^{2}=0,757, \mathrm{SE}=0,228, \mathrm{~F}_{\text {hitung }} / \mathrm{F}_{\text {tabel }}=3,482$, dan PRESS $=0,455$

Kata Kunci : antikanker, naftoquinon, HKSA, regresi komponen utama, deskriptor teoritik

\section{APPLYING PRINCIPAL COMPONENT REGRESSION FOR QUANTITATIVE STRUCTURE ACTIVITY RELATIONSHIP OF ANTICANCER COMPOUNDS OF NAPHTOQUINONE ANALOGUE}

\begin{abstract}
The Quantitative Structure-Activity Relationship (QSAR) study of naphtoquinone derivates as anticancer has been done using Principal Component Regression (PCR) analysis. The calculated atomic net charges (q) and several theoretical parametersby using PM3 semiempirical were used as descriptors on this research. All of the molecular modeling such as building molecular structure, geometry optimization, and molecular descriptor analysis have been done using Hyperchem 7.5 software package. The biological activity data is reffer to anticancer activity of naftoquinone derivates againts human cervical carcinoma as $\log \mathrm{IC}_{50}$. All of the molecular descriptors are transformed into several pricipal components and then it used as independent variables in regression analysis to evaluate QSAR equation. The result showed that the best model for naphtoquinone presented as :
\end{abstract}

$$
\log \mathrm{IC}_{50}=0.719+0.324 \mathrm{x}_{1}+0.018 \mathrm{x}_{2}-0.183 \mathrm{x}_{3}
$$


with $\mathrm{n}=13, \mathrm{r}=0.893, \mathrm{r}^{2}=0.797$, adjusted $\mathrm{r}^{2}=0.757, \mathrm{SE}=0.228, \mathrm{~F}_{\text {calc }} / \mathrm{F}_{\text {table }}=3.482$, and PRESS $=0.455$.

Keywods : anticancer, naphtoquinone, QSAR, principal component regression, theoretical descriptor

\section{PENDAHULUAN}

Kanker dengan lebih dari 100 tipe yang berbeda merupakan salah satu penyakit dengan tingkat kematian tertinggi didunia (Soni dkk, 2012). Pada tahun 2007, penyakit kanker telah menyebabkan kematian sebanyak $13 \%$ atau 7,9 milyar dari total jumlah penduduk dunia dan terus meningkat setiap tahunnya. Kanker atau malignant neoplasm dalam ilmu medisinal merupakan penyakit dengan karakteristik pertumbuhan sel yang tidak terkendali. Kanker umumnya disebabkan oleh pemakaian tembakau, konsumsi makanan yang tidak sehat, infeksi tertentu, paparan radiasi, kurangnya aktivitas fisik, obesitas, dan polutan lingkungan. Faktorfaktor ini dapat secara langsung merusak gen atau menyebabkan kesalahan kode genetik sehingga memicu mutasi sel kanker (Anand dkk, 2008). Dengan peningkatan angka kematian yang disebabkan oleh penyakit kanker maka pengembangan obat antikanker yang lebih potensial terus dikembangkan.

Senyawa kompleks organologam seperti senyawa turunan $\mathrm{Au}(\mathrm{III})$ ditiokarbamat, cisplatin, benzoisoselenazolon, dan kompleks gallium-piridin dikenal sebagai metal based drugs dengan aktivitas antikanker yang sangat tinggi (Schmitt dan Dou, 2013; Florea dan Büsselberg, 2011; Luo dkk, 2012). Akan tetapi, pengembangan senyawa obat antikanker berdasarkan logam berat ini menimbulkan banyak resiko metabolisme tubuh manusia. Dengan demikian usaha untuk menemukan obat antikanker yang lebih potensial dan aman masih sangat perlu dikembangkan. Kongkathip dkk (2003) telah berhasil mensintesis dan melakukan uji in vitro pada senyawa turunan naftoquinon dengan melakukan variasi substituen pada kerangka senyawa 1,2furanonaftoquinon, 1,2-piranonaftoquinon, 1,4-furanonaftoquinon, dan 1,4piranonaftoquinon.

Pendekatan kimia komputasi dalam upaya untuk mendesain senyawa obat menjadi sangat penting karena dapat meminimalisir penggunaan bahan kimia, lebih hemat karena dapat menghindari trial and error dalam eksperimen tetapi tetap dapat memberikan tingkat kepercayaan yang relatif tinggi. Salah satu aplikasi kimia komputasi yang paling sering digunakan dalam desain senyawa obat antaralain adalah kajian Hubungan Kuantitatif Struktur-Aktivitas (HKSA). Kajian HKSA bertujuan untuk mencari hubungan yang konsisten secara empiris antara sifat-sifat molekular dan aktivitas biologis suatu senyawa. Metode analisis yang umum digunakan dalam HKSA diantaranya adalah metode Multilinear Regression (MLR), Principal Component Regression (PCR), Artificial Neural Network (ANN), dan Partial Least Squares (PLS). Beberapa penelitian mengenai HKSA telah dilakukan dengan menggunakan metode PCR antara lain untuk aplikasi benzalaseton sebagai antimutagen (Yuliana dkk, 2004), 4anilino-3-kuinolinkarbonitril sebagai inhibitor Src kinase (Sun dkk, 2009) dan amino-pirimido-isokuinolin kuinon sebagai anti tumor (Saputra dkk, 2013). Metode PCR ini mengubah seri deskriptor molekul menjadi komponenkomponen utama yang bersifat independen satu sama lain sehingga penggunaan metode PCR dalam analisis HKSA sangat disukai mengingat metode 
ini dapat menghindari efek kolinearitas data (Ursu dkk, 2006). Berdasarkan keunggulan metode PCR daripada metode analisis yang lain maka metode inidipilih pada penelitian ini untuk digunakan pada analisis HKSA antikanker senyawa turunan naftoquinon.

\section{ALAT DAN BAHAN}

\section{Bahan}

Bahan yang digunakan dalam penelitian ini adalah 13 senyawa turunan naftoquinon dengan aktivitas biologis yang merupakan data sekunder dari hasil penelitian Kongkathip dkk.(2003) seperti yang disajikan pada Tabel 1.

Alat

Penelitian ini dilakukan menggunakan komputer dengan spesifikasi Intel ${ }^{\circledR}$ Core $^{\mathrm{TM}}$ i5-2130 CPU @ $2.90 \mathrm{GHz}$ dan sistem operasi Windows 7. Semua proses perhitungan, optimasi geometri dan analisis deskriptor teoritik senyawa turunan naftoquinon dilakukan dengan menggunakan paket program Hyperchem 7.5 dan proses analisis statistika menggunakan program SPSS 17.0.

Tabel 1.Data stuktur dan aktivitas 13 senyawa turunan naftoquinon (Kongkathip dkk. 2003).

\begin{tabular}{|c|c|c|c|c|c|}
\hline Kelompok senyawa & Struktur & No & $\mathrm{R}_{1}$ & $\mathrm{R}_{2}$ & $\mathrm{IC}_{50}$ \\
\hline \multirow{4}{*}{$\begin{array}{c}1,2- \\
\text { piranonaftoquinon }\end{array}$} & & 1 & $\mathrm{CH}_{3}$ & $\mathrm{CH}_{3}$ & 7.15 \\
\hline & & 2 & $\mathrm{H}$ & $\mathrm{H}$ & 0.92 \\
\hline & & 3 & $\mathrm{CH}_{3}$ & $\mathrm{H}$ & 1.1 \\
\hline & & 4 & $\mathrm{OH}$ & $\mathrm{H}$ & 7.83 \\
\hline \multirow{3}{*}{$\begin{array}{l}1,2- \\
\text { furanonaftoquinon }\end{array}$} & & 5 & $\mathrm{CH}_{3}$ & $\mathrm{CH}_{3}$ & 2.46 \\
\hline & & 6 & $\mathrm{CH}_{3}$ & $\mathrm{H}$ & 2.52 \\
\hline & & 7 & $\mathrm{H}$ & $\mathrm{H}$ & 2.85 \\
\hline \multirow{3}{*}{$\begin{array}{c}1,4- \\
\text { piranonaftoquinon }\end{array}$} & & 8 & $\mathrm{CH}_{3}$ & $\mathrm{CH}_{3}$ & 23.30 \\
\hline & & 9 & $\mathrm{H}$ & $\mathrm{H}$ & 9.95 \\
\hline & & 10 & $\mathrm{CH}_{3}$ & $\mathrm{H}$ & 17.89 \\
\hline \multirow{3}{*}{$\begin{array}{l}1,4- \\
\text { furanonaftoquinon }\end{array}$} & & 11 & $\mathrm{CH}_{3}$ & $\mathrm{CH}_{3}$ & 7.59 \\
\hline & & 12 & $\mathrm{CH}_{3}$ & $\mathrm{H}$ & 7.56 \\
\hline & & 13 & $\mathrm{H}$ & $\mathrm{H}$ & 9.25 \\
\hline
\end{tabular}




\section{Prosedur Kerja}

Semua stuktur molekul pada Tabel 1 dibentuk dengan opsi drawtool kemudian dilakukan model build untuk membentuk struktur molekul 3D. Pada semua struktur yang sudah dibentuk dilakukan optimasi geometri menggunakan perhitungan mekanika kuantum semiempirik PM3 (Parameterized Model 3) untuk mendapatkan struktur molekul dengan minimum potensial energy surface. Proses optimasi geometri dilakukan dengan algoritma Polak Ribiere dan batas konvergensi diatur sampai 0,001 kkal/Å.mol. Pada struktur molekul teroptimasi dilakukan pencatatan data struktur elektronik berupa muatan atom (q) pada kerangka struktur utama sesuai penomoran sesuai struktur yang disajikan pada Tabel 1 dan identifikasi sifat-sifat molekular menggunakan modul QSAR properties. Semua proses optimasi geometri dan analisis deskriptor molekul pada penelitian ini dilakukan dengan bantuan perangkat lunak Hyperchem 7.5.

Sebelum dilakukan proses PCR, terlebih dahulu dilakukan analisis komponen utama (Principal Component Analysis, PCA) dengan cara melakukan transformasi seperangkat data deskriptor molekul menjadi beberapa komponen utama yang saling independen satu sama lain. Selanjutnya komponen-komponen utama yang dihasilkan digunakan sebagai variabel bebas untuk analisis regresi PCR terhadap $\log \mathrm{IC}_{50}$ eksperimen sebagai variabel tidak bebas. Pada penelitian ini dilakukan regresi pada setiap kombinasi satu-satu komponen utama terhadap logaritma aktivitas antikanker senyawa untuk mendapatkan persamaan HKSA. Metode enter dipilih sebagai metode regresi karena metode ini memperhitungkan setiap kontribusi variabel tanpa perlu menghilangkan variabel-variabel yang kurang berpengaruh. Output dari proses regresi komponen utamaakan menghasilkan beberapa model persamaan HKSA yang akan dianalisis berdasarkan parameter statistik seperti nilai $\mathrm{r}, \mathrm{r}^{2}$, adjusted $\mathrm{r}^{2}$, Standard Error (SE), $\mathrm{F}_{\text {hitung }} / \mathrm{F}_{\text {tabel }}$, dan PRESS untuk menentukan model persamaan HKSA terbaik.

\section{HASIL DAN PEMBAHASAN}

\section{Analisis Deskriptor Molekul}

Deskriptor molekul berupa muatan atom bersih senyawa diperoleh berdasarkan analisis populasi mulliken dari struktur molekul teroptimasi menggunakan metoda semiempirik PM3. Beberapa penelitian HKSA telah menggunakan perhitungan PM3 untuk analisis sifat struktur dari senyawa kandidat obat dan sukses digunakan untuk analisis HKSA seperti pada contoh kasus turunan flavonoid sebagai inhibitor peroksidasi lipid (Liao dkk, 2006) dan turunan 1,10-fenantrolin (Hadanu dkk, 2007). Dengan demikian, perhitungan ini juga dipertimbangkan untuk digunakan pada penelitian ini. Penggunaan metode ini cukup efektif karena waktu pengerjaan relatif singkat sehingga deskriptor dapat dengan mudah diperoleh.

Tabel 2 menyajikan data deskriptor molekul meliputi muatan bersih atom (q), luas permukaan (LP), volume molekular, energi hidrasi $\left(E_{\text {hidrasi }}\right)$, lipofilisitas $(\log \mathrm{P})$, indeks refraktifitas (Refr), polarisabilitas (Pol) dan massa molekul. Deskriptor muatan atom merupakan satu-satunya deskriptor yang hanya bisa diperoleh melalui eksperimen in silico atau kimia komputasi. Muatan atom bersih diperoleh dari analisis populasi mulliken yang merupakan hasil penjumlahan muatan dalam orbital dengan muatan yang berasal dari setiap atom (Dorca and Bultinck, 2004). 
Aplikasi regresi komponen utama untuk analisis hubungan... (Andrian Saputra, dkk)

Tabel 2. Data deskriptor 13 senyawaturunan naftoquinon

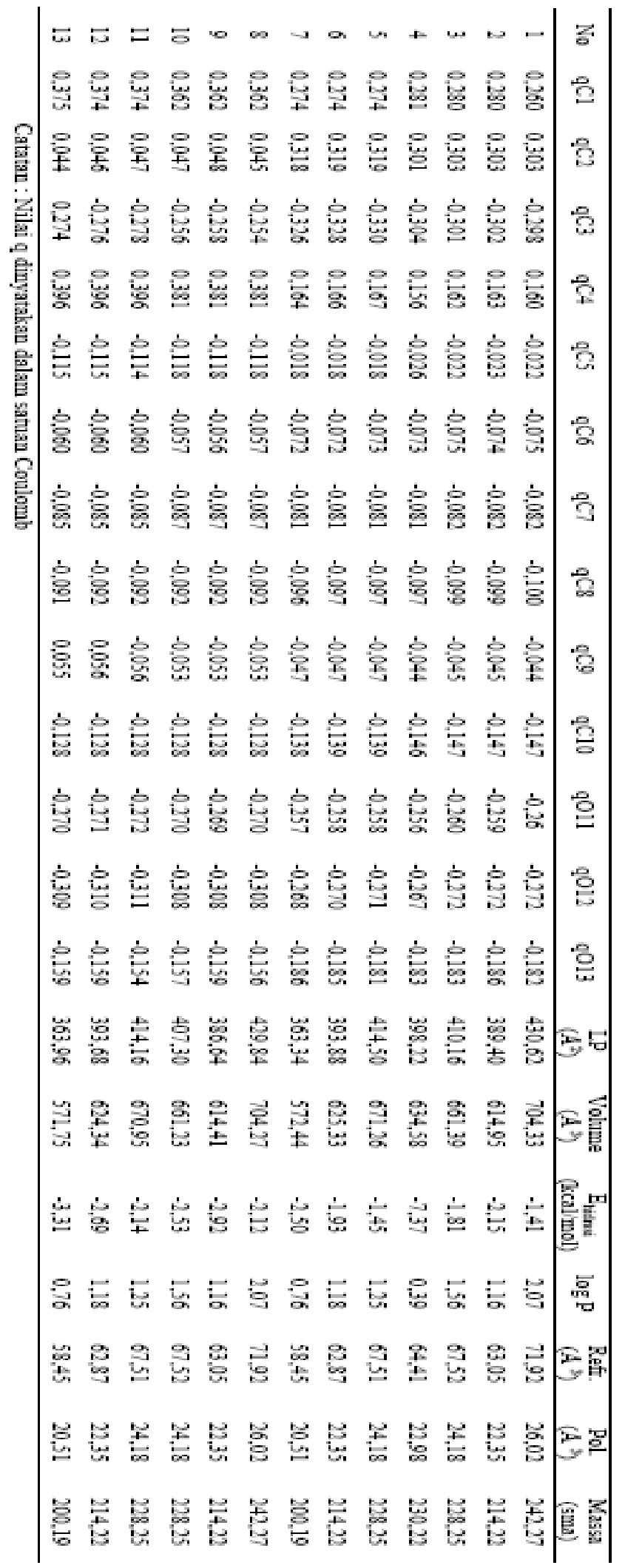


Dari tabel 2 dapat diamati bahwa perbedaan jenis dan posisi substituen dapat mempengaruhi muatan atom senyawa. Substitusi gugus-gugus yang berbeda relatif signifikan dalam mempengaruhi muatan atom senyawa terutama pada atom $\mathrm{C} 4$ dan $\mathrm{C} 5$ sedangkan pada atom-atom lainnya nilai q relatif tidak berbeda secara signifikan. Hal ini bisa dikarenakan posisi cincin siklik furan dan piran pada senyawa turunan naftoquinon yang dipelajari berada pada atom $\mathrm{C} 4$ dan $\mathrm{C} 5$ pada kerangka utama sehingga substituen secara langsung mempengaruhi muatan atom tersebut.

Perbedaan tipe analog naftoquinon juga sangat mempengaruhi efek subtitusi dan selanjutnya akan mempengaruhi aktivitas senyawa tersebut melawan sel kanker. Sebagai contoh yaitu efek substituen pada senyawa 1,2-piranonaftoquinon dan 1,2furanonatoquinon. Efek substituen pada senyawa 1,2-furanonaftoquinon tampak signifikan mempengaruhi muatan atom pada kerangka struktur utama senyawa terutama pada atom $\mathrm{C} 3, \mathrm{C} 4$, dan $\mathrm{C} 5$ dibandingkan pada 1,2-piranonaftoquinon. Muatan atom C3, C4, dan C5 pada senyawa 1,2-puranonaftoquinon berturut-turut adalah -0,298 - -0,304, 0,156 - 0,163, dan -0,022 - 0,026 Coulomb. Berbeda dengan senyawa 1,2-puranona-ftoquinon, pada senyawa 1,2-furanonaftoquinon muatan atom C3, C4, dan $\mathrm{C} 5$ berturut-turut adalah -0,326 - -0,330, 0,164 - 0,167, dan -0,018 Coulomb. Hal ini dapat dijelaskan bahwa efek induksi substituen pada senyawa 1,2furanonaftoquinon dengan cincin 5 yang lebih sederhana akan lebih mudah mempengaruhi muatan atom dari pada senyawa 1,2-puranonaftoquinon dengan cincin 6 yang lebih besar.
Selain muatan atom digunakan pula deskriptor teoritik yang lain. Salah satu deskriptor teoritik yang sangat dipertimbangkan dalam analisis HKSA adalah koefisien partisi oktanol/air (log P). Nilai $\log \mathrm{P}$ menggambarkan efektivitas distribusi senyawa kandidat obat dalam tubuh manusia. Semakin tinggi nilai $\log \mathrm{P}$ sampai batas tertentu maka obat tersebut akan lebih mudah terdistribusi dalam fasa non polar daripada fasa polar sehingga makin baik untuk dikonsumsi manusia. Dengan demikian sangat penting untuk mengikutsertakan deskriptor-deskriptor teoritik ini selain deskriptor elektronik dalam analisis HKSA agar didapatkan persamaan terbaik yang representatif terhadap setiap senyawa turunan naftoquinon. Data setiap deskriptor senyawa turunan naftoquinon disajikan dalam Tabel 2.

\section{Analisis Komponen Utama}

Analisis komponen utama digunakan untuk mentransformasi seperangkat variabel yang mungkin berkorelasi secara linear menjadi komponen-komponen utama yang saling independen satu sama lain. Efek kolinearitas data akan menyebabkan variabel bebas yang tidak berhubungan linear dengan varibel terikat menjadi ikut linear dalam analisis regresi dan hal ini akan menyebabkan kesalahan cukup besar dalam prediksi hasil HKSA. Proses analisis komponen utama akan menghasilkan beberapa informasi seperti eigenvalue initial, matrik komponen, dan data komponenkomponen utama yang masing-masing ditunjukkan pada Tabel 3, 4, dan 5 . Komponen utama yang memiliki nilai eigenvalue lebih besar dari 1 dapat dipertimbangkan untuk dimasukkan dalam regresi komponen utama. Dari data dalam tabel 3 dapat diamati bahwa 
komponen utama yang memiliki nilai eigenvalue yang lebih besar dari 1 adalah komponen 1, 2, dan 3 dengan nilai persentase variansi terbesar dari keseluruhan data. Dengan demikian komponen utama 1, 2, dan 3 dipertimbangkan menjadi komponen utama.

Berdasarkan pertimbangan ini maka pada penelitian ini dipelajari tiga model persamaan untuk dipertimbangkan untuk menjadi persamaan HKSA. Ketiga model tersebut adalah yaitu model 1 dengan 1 komponen (model 1), model 2 dengan 2 komponen (model 1 dan 2), dan model 3 dengan 3 komponen yaitu (model 1, 2, dan 3).
Tabel 4 menyajikan koefisienkoefisien matriks hasil faktor reduksi data. Matriks komponen merupakan koefisien-koefisien baru yang akan digunakan dalam kombinasi linear untuk menentukan variabel laten (Werfette dkk 2008). Hasil kombinasi linear matriks komponen hasil faktor reduksi data yang ditampilkan pada Tabel 4 terhadap nilai deskriptor molekul akan dihasilkan variabelvariabel laten seperti yang disajikan pada tabel 5. Nilai variabel laten yang diperoleh kemudian digunakan dalam analisis regresi komponen utama untuk mendapatkan kandidat persamaan terbaik HKSA antikanker turunan naftoquinon.

Tabel 3. Nilai eigenvalue dan variansi total dari faktor reduksi data

\begin{tabular}{cccc}
\hline \multirow{2}{*}{ Komponen } & \multicolumn{3}{c}{ Eigenvalue initial } \\
\cline { 2 - 4 } & Total & \% Variansi & \% Kumulatif \\
\hline 1 & 10,101 & 50,503 & 50,503 \\
2 & 6,278 & 31,390 & 81,892 \\
3 & 1,319 & 6,595 & 88,487 \\
4 & 0,977 & 4,887 & 93,374 \\
5 & 0,759 & 3,793 & 97,167 \\
6 & 0,347 & 1,737 & 98,904 \\
7 & 0,147 & 0,737 & 99,641 \\
8 & 0,048 & 0,239 & 99,880 \\
9 & 0,013 & 0,064 & 99,944 \\
10 & 0,006 & 0,031 & 99,974 \\
11 & 0,005 & 0,024 & 99,998 \\
12 & 0,000 & 0,002 & 100,000 \\
\hline
\end{tabular}

Tabel 4. Matriks komponen hasil faktor reduksi data

\begin{tabular}{lrrr}
\hline \multirow{2}{*}{ Deskriptor } & \multicolumn{3}{c}{ Komponen } \\
\cline { 2 - 4 } & \multicolumn{1}{c}{1} & \multicolumn{1}{c}{2} & \multicolumn{1}{c}{3} \\
\hline qC1 & 0,992 & $-0,031$ & $-0,019$ \\
qC2 & $-0,996$ & $-0,056$ & 0,011 \\
qC3 & 0,507 & $-0,462$ & 0,038 \\
qC4 & 0,998 & 0,028 & 0,012 \\
qC5 & $-0,995$ & $-0,060$ & 0,023 \\
qC6 & 0,975 & 0,042 & $-0,033$ \\
qC7 & $-0,934$ & $-0,214$ & $-0,067$ \\
\hline
\end{tabular}


Aplikasi regresi komponen utama untuk analisis hubungan... (Andrian Saputra, dkk)

\begin{tabular}{lrrr}
\hline qC8 & 0,953 & $-0,153$ & $-0,122$ \\
qC9 & 0,424 & $-0,512$ & 0,059 \\
qC10 & $-0,187$ & $-0,171$ & 0,599 \\
qO1 & $-0,976$ & $-0,137$ & $-0,104$ \\
qO2 & $-0,994$ & $-0,075$ & $-0,050$ \\
qO3 & 0,983 & 0,153 & $-0,048$ \\
LP & $-0,063$ & 0,978 & $-0,084$ \\
Volume & $-0,037$ & 0,986 & $-0,085$ \\
Ehidrasi $_{\text {log P }}$ & 0,008 & 0,372 & 0,815 \\
Refr & 0,115 & 0,856 & 0,403 \\
Pol & $-0,030$ & 0,990 & $-0,061$ \\
Massa & $-0,032$ & 0,990 & $-0,068$ \\
\hline
\end{tabular}

Tabel 5. Variabel laten hasil kombinasi linear matrik 3 komponen utama terhadap data deskriptor

\begin{tabular}{cccc}
\hline \multirow{2}{*}{ Senyawa } & \multicolumn{3}{c}{ Variabel laten } \\
\cline { 2 - 4 } & $\mathbf{x}_{\mathbf{1}}$ & $\mathbf{x}_{\mathbf{2}}$ & $\mathbf{x}_{\mathbf{3}}$ \\
\hline 1 & $-0,80436$ & 1,49572 & 0,44843 \\
2 & $-0,90915$ & $-0,64486$ & 1,89214 \\
3 & $-0,80356$ & 0,55165 & 0,26554 \\
4 & $-1,01230$ & $-0,11608$ & $-2,83243$ \\
5 & $-0,83561$ & 0,54545 & 0,11537 \\
6 & $-0,89093$ & $-0,32183$ & 0,23589 \\
7 & $-0,95594$ & $-1,36370$ & 0,07605 \\
8 & 1,09920 & 1,50424 & 0,10140 \\
9 & 0,95898 & $-0,38015$ & $-0,11889$ \\
10 & 1,03073 & 0,55221 & $-0,04277$ \\
11 & 0,99387 & 0,57569 & $-0,13051$ \\
12 & 1,01153 & $-0,54771$ & 0,05602 \\
13 & 1,11755 & $-1,85063$ & $-0,06624$ \\
\hline
\end{tabular}

\section{Analisis Hasil Regresi Komponen Utama}

Proses regresi komponen utama menggunakan data variabel laten $\left(\mathrm{x}_{1}\right.$, $\mathrm{x}_{2}$ dan $\mathrm{x}_{3}$ ) hasil transformasi dari deskriptor teoritik sebagai variabel bebas dan $\log \mathrm{IC}_{50}$ eksperimen sebagai variabel tidak bebas. Penentuan

Tabel 6. Parameter statistik tiga model persamaan HKSA hasil regresi komponen utama

\begin{tabular}{ccccccc}
\hline Model & $\mathrm{r}$ & $\mathrm{r}^{2}$ & adjusted $^{2}$ & $\mathrm{SE}$ & $\mathrm{F}_{\text {hitung }} / \mathrm{F}_{\text {tabel }}$ & PRESS \\
\hline $\mathbf{1}$ & $\mathbf{0 , 7 4 7}$ & $\mathbf{0 , 5 5 8}$ & $\mathbf{0 , 5 1 8}$ & $\mathbf{0 , 3 0 1}$ & $\mathbf{2 , 8 6 5}$ & $\mathbf{0 , 9 9 6}$ \\
$\mathbf{2}$ & $\mathbf{0 , 7 8 7}$ & $\mathbf{0 , 6 2 0}$ & $\mathbf{0 , 5 4 3}$ & $\mathbf{0 , 2 9 3}$ & $\mathbf{1 , 9 8 4}$ & $\mathbf{0 , 8 5 7}$ \\
$\mathbf{3}$ & $\mathbf{0 , 8 9 3}$ & $\mathbf{0 , 7 9 7}$ & $\mathbf{0 , 7 5 7}$ & $\mathbf{0 , 2 2 8}$ & $\mathbf{3 , 4 8 2}$ & $\mathbf{0 , 4 5 5}$ \\
\hline
\end{tabular}


persamaan terbaik HKSA menggunakan beberapa paramater statistik yaitu nilai koefisien korelasi (r), koefisien determinasi $\left(\mathrm{r}^{2}\right)$, adjusted $\mathrm{r}^{2}$, standard of error $(\mathrm{SE})$, dan $\mathrm{F}_{\text {hitung }} / \mathrm{F}_{\text {tabel }}$. Nilai $\mathrm{r}$ dan $\mathrm{r}^{2}$ memberikan gambaran mengenai kekuatan korelasi antara variabel bebas (deskriptor) dan variabel tidak bebas(log $\left.\mathrm{IC}_{50}\right)$ serta seberapa baik tingkat linearitas model persamaan tersebut untuk memprediksi variabel yang lain. Dari tabel 4 dapat diamati bahwa dengan pembulatan sampai 3 desimal menghasilkan nilai koefisien korelasi (r) model 1-3 memiliki nilai yaitu $0,747,0,787$ dan 0,893 sedangkan nilai koefisien determinasi $\left(\mathrm{r}^{2}\right)$ model 13 memiliki nilai yaitu $0,557,0,620$ dan 0,797 . Analisis selanjutnya yaitu nilai adjusted $\mathrm{r}^{2}$ yang merupakan nilai $\mathrm{r}^{2}$ yang telah dikoreksi terhadap jumlah variabel. Nilai adjusted $\mathrm{r}^{2}$ yang digunakan ini lebih peka terhadap estimasi kesalahan yang terdapat dalam setiap persamaan. Dari tabel 6 dapat diamati bahwa nilai model 3 yang merupakan hasil regresi terhadap tiga komponen utama yang memiliki nilai adjusted $\mathrm{r}^{2}$ terbesar yang mengindikasikan bahwa model 3 memiliki ketelitian yang baik dalam menggambarkan hubungan variabel bebas dan tidak bebas dengan tingkat kesalahan yang relatif kecil. Hal ini juga didukung oleh data standard of error dimana model 3 memiliki error yang relatif kecil dibandingkan dengan model yang lain.

Analisis parameter statistik berikutnya adalah $F_{\text {hitung }} / F_{\text {tabel }}$. Nilai $\mathrm{F}_{\text {hitung }} / \mathrm{F}_{\text {tabel }}$ mampu menggambarkan tingkat signifikansi data dengan tingkat kepercayaan pada penelitian ini sebesar $95 \%$. Semakin besar nilai $F_{\text {hitung }} / F_{\text {tabel }}$ maka data akan semakin signifikan. Mengingat model 1-3 memiliki nilai $F_{\text {hitung }} / F_{\text {tabel }}>1$ maka diasumsikan semua model dapat diterima secara statistik.
Dengan demikian berdasarkan analisis statistik menggunakan parameter $r, r^{2}$, adjusted $\mathrm{r}^{2}, \mathrm{SE}, \mathrm{F}_{\text {hitung }} / \mathrm{F}_{\text {tabel }}$ maka model 3 memiliki nilai parameter statistik yang relatif signifikan dibandingkan dengan model lainnya sehingga model 3 dinilai cukup baik untuk menggambarkan hubungan kuantitatif deskriptor teoritik terhadap aktivitas antikanker senyawa turunan naftoquinon. Akan tetapi kriteria pemilihan menggunakan parameter statistik ini masih perlu dilakukan pengujian model persamaan HKSA menggunakan nilai PRESS untuk mengetahui seberapa baik tingkat prediksi model persamaan HKSA terhadap nilai aktivitas biologis $\log \mathrm{IC}_{50}$ hasil eksperimen.

\section{Pengujian Model Persamaan HKSA}

Pengujian model persamaan berdasarkan kedekatan hasil prediksi model tersebut terhadap nilai yang telah ditentukan dari hasil eksperimen perlu dilakukan untuk menentukan model terbaik HKSA. Metode yang umum digunakan dalam pengujian model persamaan HKSA adalah nilai PRESS (predictive residual sum of square). Nilai PRESS ini merupakan kuadrat dari selisih nilai logaritma aktivitas biologis senyawa hasil prediksi dikurangi dengan logaritma aktivitas biologis senyawa yang didapatkan dari hasil eksperimen sehingga penggunaan metode PRESS cukup relevan untuk menggambarkan seberapa baik tingkat prediksi model persamaan HKSA yang terkait terhadap hasil eksprimen. Model persamaan HKSA terbaik dipilih berdasarkan nilai PRESS yang terkecil (Puspitasari dkk, 2006). Berdasarkan data PRESS dalam tabel 6 dapat diamati bahwa model 3 memiliki nilai PRESS terkecil sehingga berdasarkan analisis parameter statistik dan uji PRESS maka model 3 dipertimbangkan untuk 
menjadi model persamaan terbaik HKSA antikanker senyawa turunan naftoquinon. Model persamaan HKSA dalam penelitian ini ditampilkan dalam Gambar 1.

Apabila dilihat dari kerangka struktur senyawa turunan naftoquinon terdapat gugus-gugus yang diprediksi merupakan situs aktif senyawa seperti gugus karbonil. Perbedaan posisi gugus karbonil ini akan memberikan aktivitas inhibisi yang berbeda-beda seperti pada kasus 1,2-piranonaftoquinon dan1,4piranonaftoquinon begitupula dengan 1,2-furanonaftoquinon dan 1,4-

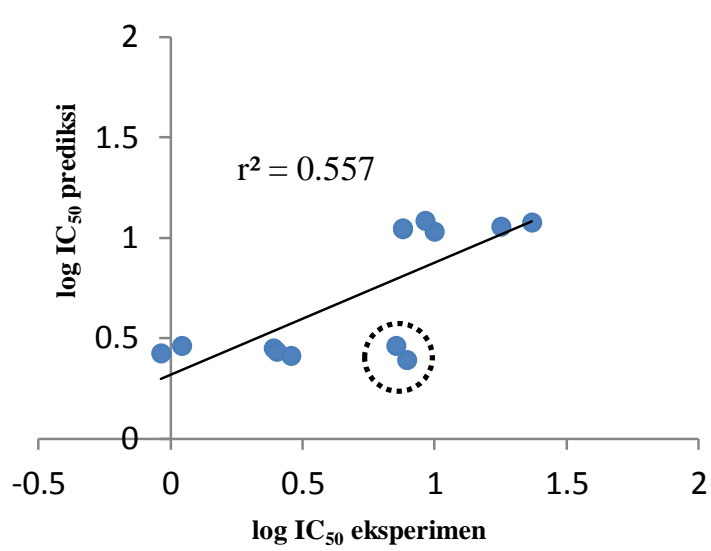

furanonaftoquinon. Perbedaan cincin siklis juga ikut memberikan kontribusi terhadap aktivitas biologis senyawa karena akan mempengaruhi kemudahan induksi elektron dari gugus-gugus substituen pada kerangka struktur utama senyawa. Selanjutnya penambahan gugus-gugus hidrofobik diprediksi dapat meningkatkan lipofilisitas senyawa dan deskriptor teoritik lainnya seperti volume, luas permukaan dan sebagainya guna mendesain senyawa baru yang lebih potensial.

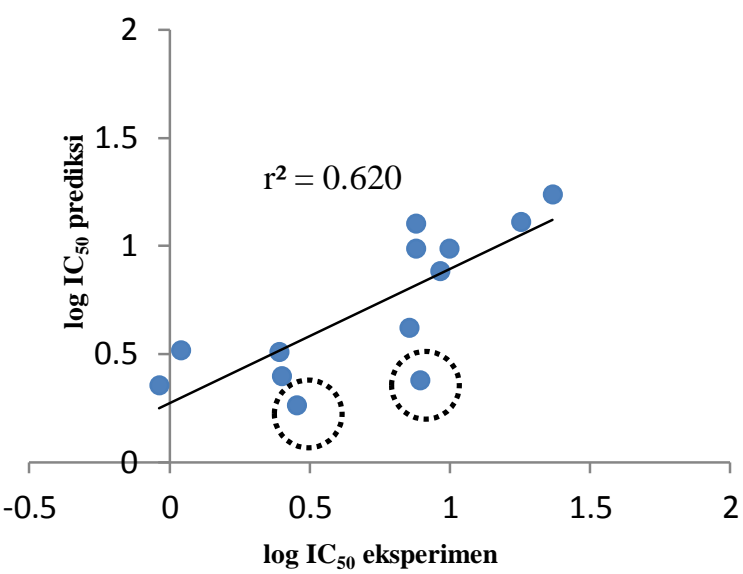
a. $\log \mathrm{IC}_{50}=0,719+0,324 \mathrm{x}_{1}$
b. $\log \mathrm{IC}_{50}=0,719+0,324 \mathrm{x}_{1}+0,018 \mathrm{x}_{2}$

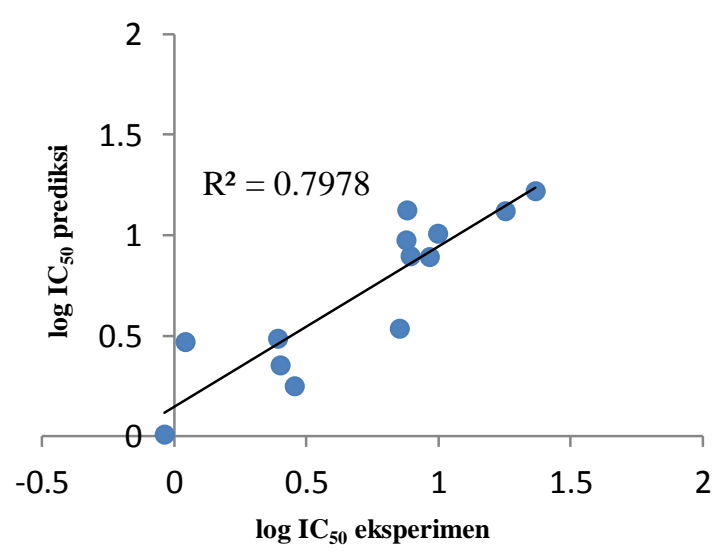

$$
\text { c. } \log I C_{50}=0,719+0,324 x_{1}+0,018 x_{2}-0,183 x_{3}
$$

Gambar 1. Grafik hubungan antara aktivitas antikanker prediksi dan eksperimen (a) model 1, (b) model 2 dan (c) model 3. Data di dalam lingkaran garis putus secara kualitatif menggambarkan data pencilan (outlier). 


\section{KESIMPULAN}

Teknik regresi komponen utama telah dapat digunakan untuk menentukan persamaan terbaik HKSA antikanker senyawa turunan naftoquinon dengan deskriptor teoritik dari hasil perhitungan semiempirik PM3 sebagai variabel bebas dan $\log \mathrm{IC}_{50}$ sebagai variabel tidak bebas. Berdasarkan analisis parameter statistik dan uji PRESS dipilih model persamaan terbaik HKSA yang direpresentasikan sebagai berikut :

$\log I C_{50}=0,719+0,324 x_{1}+0,018 x_{2}-$ $0,183 \times 3$

Model persamaan ini diperoleh untuk 13 senyawa turunan nafotuqinon dengan nilai $r=0,893, r^{2}=0,797$, adjusted $\mathrm{r}^{2}=0,757$, standard of error $=$ $0,228, \mathrm{~F}_{\text {hitung }} / \mathrm{F}_{\text {tabel }}=3,482$ pada tingkat signifikansi 95\%, dan PRESS $=0,455$.

\section{DAFTAR PUSTAKA}

Anand, P., Kunnumakara, A. B., Sundaram, C., Harikumar, K. B., Tharakan, S. T., Lai, O. S., Sung, B., dan Aggarwai, B. B., 2008, Cancer is a Preventable Disease that Requires Major Lifestyle Changes, Pharm. Res., Vol. 25, No. 9, 2097-2116

Dorca, R. C., dan Bultinck, P., 2004, Quantum Mechanical Basis For Mulliken Population Analysis, $J$. Math. Chem., Vol. 36, No. 3, 231239

Florea, A.M., danBüsselberg, D., 2011, Cisplatin as An Antitumor Drug: Cellular Mechanisms of Activity Drug Resistance and Induced Side Effects, Cancers, Vol. 3, 13511371

Hadanu, R., Mastjeh, S., Jumina, Mustofa, Sholikhah, E. N.,
Wijayanti, M. A., dan Tahir, I.,Perhitungan Deskriptor Dengan Melibatkan Anion Garam: Analisis Hubungan Kuantitatif Struktur-Aktivitas Senyawa Anti Malaria Turunan 1,10Fenantrolin, Marina Chimica Acta, Vol. 1, No. 2, 11-18

Kongkathip, N., Kongkathip, B., Siripong, P., Sangma, C., Luangkamin, S., Niyomdecha, M., Pattanapa, S., Piyaviriyagul, S., dan Kongsaeree, P., 2003, Potent Antitumor Activity of Synthetic 1,2-Naphthoquinonesand 1,4Naphthoquinones, Bioor.\& Med. Chem., Vol. 11, 3179-3191

Liao, H. R., Chang, Y. S., Lin,Y. C., Yang, L. L., Chou, Y. M., dan Wang, B. C., 2006, QSAR analysis of the Lipid Peroxidation Inhibitory Activity with Structure and Energetics of 36 Flavonoids Derivatives, J. Chin. Chem. Soc., Vol. 53, 1251-1261

Luo, Z. H., He, S. Y., Chen, B. Q., Shi, Y. P., Liu, Y. M., Li, C. W., danWang, Q. S. 2012, Synthesis and In Vitro Antitumor Activity of 1,3,4-Oxadiazole Derivatives Based on Benzisoselenazolone, Chem. Pharm. Bull., Vol. 60, No.7, 887-891

Puspitasari, N. S., Mudasir, dan Tahir, I., 2006, Aplikasi Principal Component Regression untuk Analisis QSAR Senyawa Antioksidan Turunan Flavon/Flavonol Menggunakan Deskriptor Elektronik Hasil Perhitungan Metode AM1, Berkala MIPA, Vol. 16, No. 3, 19-26 
Saputra, A., Wijaya, K., dan Tahir, I., 2013, Hubungan Kuantitatif Struktur Elektronik dan Aktivitas Anti Tumor Senyawa Turunan Amino Pirimido Isokuinolin Kuinon Dengan Pendekatan Regresi Komponen Utama, Chemistry Progress, Vol. 6, No.1, 10-17

Schmitt, S., dan Dou, Q. P.,2013, Metal-Based Compounds as Proteasome-Inhibitory AntiCancer Drugs, J. Pharmacovigilance, Vol. 1, No. 1, 1-3

Soni, B., Ranawar, M. S., Bhandari, A., dan Sharma, R., 2012, Synthesis and Invitro Anti Tumor Activity of Benzimidazole Derivates, Int. J. Drug Res. Tech., Vol. 2, No. 7, 479-485

Sun, M., Zheng, Y., Wei, H., Chen, J., dan Ji, M., 2009, QSAR Studies on 4-Anilino-3-Quinolinecarbonitriles as Src Kinase Inhibitors Using Robust PCA and Both Linear and Nonlinear Models, $J$. Enzyme Inhibit. \& Med. Chem., Vol. 24, No.5,1109-1116

Ursu, O., Costescu, A., Diudea, M. V., dan Parv, B., 2006, QSAR Modeling of Antifungal Activity of Some Heterocyclic Compounds, Croatica Chimica Acta, Vol. 79, No.3, 483-488

Yuliana, Pranowo, H. D., Jumina, dan Tahir, I., 2004, Quantitative Electronic Structure-Activity Relationships Analysis Antimutagenic Benzalacetone Derivatives by Principal Component Regression Approach, Indo. J. Chem., Vol. 7, No.1, 7277

Werfette, P. R. M., Armunanto, R., dan Tahir I., 2008, Quantitative Electronic Structure-Activity
Relationship Analysis of Antimutagenic Benzalacetone Derivates By Principal Component Regression Approach, Indo. J. Chem., Vol. 4, No. 1, 6875 